\title{
Intermédialités
}

Histoire et théorie des arts, des lettres et des techniques

Intermediality

History and Theory of the Arts, Literature and Technologies

\section{Sophie Calle: Follow me}

\section{Martine Delvaux}

Numéro 7, printemps 2006

Filer (Sophie Calle)

Shadowing (Sophie Calle)

URI : https://id.erudit.org/iderudit/1005522ar

DOI : https://doi.org/10.7202/1005522ar

Aller au sommaire du numéro

Éditeur(s)

Centre de recherche sur l'intermédialité

ISSN

1705-8546 (imprimé)

1920-3136 (numérique)

Découvrir la revue

Citer cet article

Delvaux, M. (2006). Sophie Calle: Follow me. Intermédialités / Intermediality, (7), 151-164. https://doi.org/10.7202/1005522ar
Résumé de l'article

Cet article aborde la question de l'identité sexuelle dans l'oeuvre de Sophie Calle, en particulier dans Des histoires vraies + dix et No Sex Last night. Il s'agira de montrer, d'une part, que l'utilisation de stéréotypes sexuels par l'artiste et, d'autre part, l'importance qu'elle accorde au désir et à l'échec des rencontres amoureuses ont pour effet d'ébranler le concept d'identité, qu'il s'agisse d'identité sexuelle ou simplement de biographie. 


\title{
Sophie Calle: Follow me
}

\author{
Martine Delvaux
}

S

ophie Calle's installations use text and image as traces of performative rituals

which structure her life and her work: "Jeune," she says, "jai été victime de mes sentiments et j'en ai souffert. Essayer de ne pas souffrir est au cœur de mon travail. Je m'impose des règles pour m'aider à vivre." These rules and rituals by which she abides, as well as those she invites or forces people to participate in, render the ordinary extraordinary and estrange daily life. Under Calle's hand, and in her eye, clichés of what makes up everyday "reality" - celebrating one's birthday, sleeping, eating, traveling, walking around, making a phone call, having sex...-and the habitual places that we live in-the street, the kitchen, the bed, the hotel room, the cemetery, the museum...-are revealed as both banal and unusual, familiar and peculiar... There, Calle looks for the unexpected, the untold and the unseen: a hotel room temporarily empty of its guests, beds occupied with people deeply asleep, a city bench or a telephone booth and the mysterious stories that they hold... She then publishes her notes and photographs, archiving non-events and empty performances while giving the illusion that she is actually presenting us with clues to the enigma of her work and identity. Indeed, Calle makes ample use of clichés, photographs as well as gender stereotypes and psychoanalytic truisms around the make-up of identity. But playing with what could be deemed a complete form of presence, she persistently misleads us, her audience, seducing us into following her but precluding any authentic end to be reached: we do not know what goal the events she organizes serve, what truth they contain, nor their creator's true self. Throughout her pieces, Calle has us wonder who, as an artist and as a woman, she really is and what she really wants; refusing to show herself directly, entirely or absolutely, she remains elusive, a shadow

1. Michel Guerrin, "Sophie Calle, fétichiste de sa propre vie," Le Monde, Saturday, September 11, 1998, p. 22. 
who we are invited to follow through performances which consistently place and displace, invest and divest tropes surrounding sexuality, gender and desire.

Christine Angot, in an interview with Calle for Beaux Arts magazine, asks: "Que faites-vous contre la tristesse?" Answering in place of the artist, she writes: "Je suis un homme. On peut faire la liaison ou pas, en fait on ne doit pas la faire. Je suis/un homme. Et non pas je suiz-un homme."2 Through a pun on the verbs "to be" and "to follow" Angot emphasizes Calle's quest-her need to follow men-as a move that does not point to a desire to be a man or even to be with a man, but that concerns a need to mark out the space between the sexes: a space of difference, a liminal space that connects presence and absence, reality and fiction; the desiring place of no sex. As Stéphane Bouquet writes about No Sex Last Night: "le sexe, ici, n'est pas le contact de deux épidermes, il est l'absence autour de quoi tournent les partenaires, le vide où ils s'affrontent du regard, mi-terrorisés mi-perdus." Sophie Calle and the men that haunt the "life" that she presents as her own in the autobiographical piece Des histoires vraies + dix ${ }^{4}$ and the film No Sex Last Night/Double Blind (Calle, 1992), are brought together in impossible (sexual) encounters and differing (sexual) identities, all of which take part in an aesthetic project that has to do with a shadowing of reality.

It is a well-known fact: a space of difference is at work in photography. As Maurice Blanchot has suggested:

[...] l'essence de l'image est d'être toute dehors, sans intimité, et cependant plus inaccessible et mystérieuse que la pensée du for intérieur; sans signification, mais appelant la profondeur de tout sens possible; irrévélée et pourtant manifeste, ayant cette présence-absence qui fait l'attrait et la fascination des sirènes5.

2. Christine Angot, "Sophie Calle par Christine Angot. No sex," Beaux Arts magazine, No. 234, November 2003, p. 80-87.

3. Stéphane Bouquet, "Ennuis de noce," Cahiers du cinéma, No. 498, January 1996, p. 72.

4. Sophie Calle, Histoires vraies + dix, Arles, Actes sud, 2002. Henceforth, reference to this work will be indicated as "HVD," followed by the page number in parentheses in the body of the text.

5. Maurice Blanchot, L'espace littéraire, quoted in Roland Barthes, La chambre claire. Note sur la photographie, Paris, Éditions des Cahiers du cinéma, Éditions Gallimard, Éditions du Seuil, 1980, p. 164-165. Henceforth, reference to Roland Barthes's work will be indicated as "CC," followed by the page number, in parentheses in the body of the text. 
This ghostlike quality of photography-what Blanchot calls absence-as-presence-is conjured up in seminal essays such as Roland Barthes's La chambre claire and Susan Sontag's On Photography ${ }^{6}$, amongst others. Both critics underline the fact that photography superimposes reality (or the present) and the past: every picture, taken in the present of a "living" object, carries with it "cette chose un peu terrible" that is, for Barthes, "le retour du mort." "[L] a photographie a quelque chose à voir avec la résurrection" (CC, p. 129), he writes; "La Vie/La Mort: le paradigme se réduit à un simple déclic, celui qui sépare la pose initialed du papier final." (CC, p. 145) Barthes's reading of Photography accentuates the fact that what is represented in the picture actually existed, the image shows what, at one point, truly was. Hence, what Barthes calls the "ça a été" ("what has been") is manifest in any picture: the picture, akin to a corpse, certifies that the referent once existed and that it does not anymore. This echoes Susan Sontag's criticism of the fact that, in contemporary occidental society, the desire to photograph is a desire "to reexperience the unreality and remoteness of the real" (op, p. 64): "A way of certifying experience," she writes, "taking photographs is also a way of refusing it-by limiting experience to a search for the photogenic, by converting experience into an image, a souvenir." (OP, p. 9) For Sontag, to photograph is to experience and create distance by giving the illusion of proximity.

Sophie Calle's work with narrative and photographs has to do with her relationship with the present and reality, to what we think we are able to know and to see. Whether by locking up unused birthday gifts in a glass chest for them to be displayed like works of art and kept away like corpses in a mausoleum, or by asking people to describe paintings stolen from a museum, Calle approaches the present as already past or impossible to grasp, forestalling the future by forbidding objects to actually "have a life." She fabricates reality, stages and controls it through rituals and actions, hindering our ability to distinguish between it and fiction. For Calle, life is the result of chance events and encounters, and reality is a tale we tell ourselves. Incidentally, identity (and sexual identity in particular) is never assured; it is a construct to play with rather than a reality that we can count on.

Indeed, while Calle's work is clearly and openly autobiographical, and her person-body and personal/social identity-everywhere performed, she constantly blurs boundaries between the factual and the fictional, between who we are, what happens to us, how we exist, and the stories that we tell about all of

6. Susan Sontag, On Photography, New York, Picador, USA, Farrar, Straus and Giroux, 1990. Henceforth, reference to this work will be indicated as "OP," followed by the page number, in parentheses in the body of the text. 
this. Calle's work clearly carries her signature and is constantly invested by her life and biography-as Alfred Pacquement writes, she is a "first-person artist" nonetheless, it intimately relies on the participation of others who she follows, investigates, interrogates, and whose traces she documents. People walk through Calle's life by means of temporary rituals which they are invited to participate in; they are an integral element of her performances. In every case, they take part in events that estrange the present, reveal the fleeting quality of time but also its endless repetition. Hence, Calle's pieces are a witness to the fact that she never acts alone and that her works are not the result of an author identifiable as what Claire Parnet calls an "objet de recognition." 7 One could even say that Calle lives by proxy, relying not only on people's memory to recreate lost places or objects, but on their willingness to experiment certain situations in her place. Calle uses other people's lives to create her own art either by inviting them to participate directly in the "situations arbitraires" "that she takes pleasure in setting up", going as far as relying on their imagination to live her own life, as in the case of Paul Auster who used her as the basis for the character of Maria in Leviathan: Calle took it upon herself to stage some of the performances invented and described by Auster, the results of which were published in Gotham Handbook.

A virtual life, a virtual relationship: Calle's impersonation of Maria impersonating Calle is but an example of the way in which her work resembles a hall of mirrors where reality and fiction can never be differentiated. Jean Baudrillard's description of Calle's work underlines its quality as a never-ending quest or filature: "Suivre quelqu'un mais pas pour le rejoindre, faire dormir les gens dans son lit, mais sans coucher avec: toujours le même déplacement, le même léger clinamen." ${ }^{1 \circ}$ Indeed, Calle's strategy consists in investing desire without allowing

7. Gilles Deleuze, Claire Parnet, Dialogues, Paris, Éditions Flammarion, coll. "Champs," 1996, p. 32.

8. Michel Guerrin, "Sophie Calle, fétichiste de sa propre vie," p. 22.

9. As in Les dormeurs where she invited people, known and unknown, to give her a few hours of their sleep, in her bed, while she photographed them) or by following them anonymously (as in Filatures parisiennes (1978-79) and Suite vénitienne [1980]). Or again, by looking for a vestige of their presence as in Une jeune femme disparaît, one of Calle's recent pieces where she took pictures of a young woman's burnt apartment: the woman, Bénédicte, worked at the Centre Pompidou, where Calle was preparing her 2003 exhibit, and was a fan of her work. On the night of the fire, she ran out of her apartment and was never seen again...

10. Jean Baudrillard, "Please follow me," in Sophie Calle, Écrits sur l'image, Paris, Éditions de l'Étoile, 1983 , p. 81. 
its release, forestalling completion and an attainment that could change reality. Few meetings take place, no conclusions can be drawn, no objectives appear to be achieved: Calle's world is one of never-ending desires where identities remain veiled, sexual encounters aborted, genders troubled, and truth or reality consequently put into question.

If both Barthes and Sontag point to photography's particular relationship to reality, they also underscore its sexual "nature." Although opposite, Barthes and Sontag's readings bring tropes of sexuality into play (something that Jane Gallop echoes in her recent essay Living with his Camera $\left.{ }^{11}\right)$. In Barthes's case, photography is sexualized by means of the mother-figure. Throughout La chambre claire, Barthes discusses his love of certain photographs, his goal being to analyze what it is about these pictures specifically and about photography in general that moves him so. Uncovering the nature of photography in a picture of his mother as a child, Barthes's investigation gives rise to a discourse that ceaselessly makes reference to motherhood and femininity, as in the following remark: "Une sorte de lien ombilical relie le corps de la chose photographiée à mon regard: la lumière, quoique impalpable, est bien ici un milieu charnel, une peau que je partage avec celui ou celle qui a été photographié." (cC, p. 126-127) Indeed, something that may recall incest lies at the heart of the tale Barthes tells of photography. One could say that Oedipus's ghost haunts the pages of La chambre claire. As Jane Gallop points out, Barthes replaces the photograph that he could include of his mother ${ }^{12}$ by one of 19 th century photographer Nadar's picture entitled The Artist's Mother (or Wife) (cC, p. 109). "In the very place where we expect to see Barthes's mother," she writes, "we find this photograph" (LWC, p. 35) - a picture, in fact, of Nadar's wife. Barthes chooses to not (directly) show the Winter Garden picture-the picture of his mother as a child - for fear that we, the viewers/readers of his book will be unable to share what he feels. Instead, he gives us Nadar and the

11. Jane Gallop, Living with his Camera, Durham, London, Duke University Press, 2003. Henceforth, reference to this work will be indicated as "LWC," followed by the page number, in parentheses in the body of the text. Gallop muses on the incestuous undertones of Barthes's relationship to his mother.

12. What Gallop does not say, however, is that the picture that refers to his mother is most probably included in the book but not identified as such. The picture on page 163 recalls the description provided of the Winter Garden photograph. See Jacques Derrida, "Les morts de Roland Barthes," in Psyché. Inventions de l'autre, Paris, Éditions Galilée, 1998 [1987], p. 273-304. 
ambiguous identity of its subject, the photo's title capturing what Barthes felt for his own mother. This confusion, writes Gallop, "is the very heart of the oedipal taboo." (LWC, p. 35)

While incest haunts La chambre claire, another excessive figure of sexuality is conjured up in Susan Sontag's On Photography: that of rape. Following Diane Arbus, who described photography as "a naughty thing to do," Sontag says of the possession of a camera that it can "inspire something akin to lust" (OP, p. 179), a lust that translates, however, into a practice of aggression. Sontag plays with the camera/phallus and camera/gun tropes, linking the truisms to "a man's fantasy of having a gun, knife, or tool between his legs." (op, p. 14) However, if holding the camera, for a woman, can be seen as a forceful attitude, a way of "owning" the phallus/gun, for Calle this is not where power lies. Hervé Guibert described Calle, at the beginning of her career, as unable to take a decent picture. In fact, the artist now most often hands her camera to a photographer other than herself, an indicative gesture of the place she occupies and the way she does not find power in the phallus/camera. Indeed, the phallus, in Calle's work, is endlessly displaced, erased, forgotten. And while the narratives she tells may appear to point to a simple psychoanalytical explanation ${ }^{13}$, their irony pre-empts any serious reading of the kind.

Indeed, throughout Des histoires vraies + dix, Calle clearly plays with psychoanalytic tropes, highlighting with humor the way in which her "life" imitates Freud's art. For instance, she retells how her father sets up an appointment for her to see a doctor because she has persistent bad breath. On her arrival at the doctor's office, Calle quickly understands that this is not a generalist but a psychoanalyst. Knowing her father's hostility towards this practice, she explains to the doctor that a mistake has been made, that her father had sent her to a generalist because she has bad breath. The psychoanalyst responds: "Vous faites toujours ce que votre père vous dit de faire?" (HVD, p. 33) Calle ends the caption by saying that she became his patient: the accompanying picture is of Freud's couch in London.

Calle begins her true stories with a (false) tale of origin which portrays her as an illegitimate child who does not know the identity of her biological father. While this story is false, every male figure made to appear thereafter in Des

13. An interpretation such as that offered by critic Penny Cousineau in her article on Calle's ultimate search for male validation, of which she says that, while it may have been received, it is "forced, stolen and ultimately empty." See Penny Cousineau, "In my fantasies, I'm the man.' Sophie Calle's True Stories," Parachute, No. 82, spring 1996, p. $10-15$. 
histoires vraies + dix - and men are present in a majority of tales, as fathers, lovers, doctors, waiters...-recalls this absent father, either in the form of a presence that replaces him or of an absence that represents him (as absent). But things are more complex, for everything and everybody, in Calle's stories, is located somewhere on the spectrum between truth and fiction, blindness and vision. Blindness is a staple of Calle's art. Like her friend Guibert who wrote a novel in which were staged blind characters, in 1986 Calle asked people blind from birth to describe their image of beauty, exhibiting portraits of those interviewed and pictures of the image described. Furthermore, the title chosen for her 2004 exhibit at the Centre Pompidou, M'as-tu vue?, alludes to this preoccupation with sight: "Did you see me?" or "Have you seen me?" this phrase says. But in its inference of an injunction: "Look at me!," it also suggests a form of exhibitionism. Much of Calle's work indeed has to do with seeing or not seeing, being seen or not being seen. Photographing absence (an empty bed, a burnt apartment, the place where a painting used to be...), Calle's camera captures the unseen as if the artist herself were blind, as if something always escaped her gaze. Neither picture nor text can seize reality; we can never be assured of what we see, we can never know if we are presented with fiction or reality.

The trope of blindness evokes Oedipus as do Calle's supposed illegitimacy, her mysterious origins and relationships with more mature male partners as well as her general fascination with men that she does not know and chooses to stalk (as in Suite vénitienne), whose identity she tries to uncover (as in Le carnet d'adresses) or whose bodies she tries to clothe (as in La cravate). Calle insists on staging a malaise concerning identity and, more specifically, sexual identity. Playing with the frame offered by the Oedipus complex (origins, father figure, enigmas, flight...), it is Oedipus himself that Calle does not wish to see, thumbing her nose at Freudian tales and psychoanalysis's most important figure. Indeed, one could say of Calle that she is like Kafka for whom photography is a way of driving things out of his mind and stories a way of shutting his eyes (quoted in CC, p. 88): rather than the mark of a trauma or an act of punishment, blindness, for Calle, is a way to see and hence to not see reality.

Describing the punctum, Barthes writes that

[...] au fond - ou à la limite - pour bien voir une photo, il vaut mieux lever la tête ou fermer les yeux. [...] La subjectivité absolue ne s'atteint que dans un état, un effort de silence (fermer les yeux, c'est faire parler l'image dans le silence). La photo me touche si je la retire de son bla-bla ordinaire: "Technique," "Réalité," "Reportage," "Art," etc.: ne rien dire, fermer les yeux, laisser le détail remonter seul à la conscience affective. (CC, p. 88-89) 
Lightning-like, the punctum blinds the viewer, and therein lies its eroticism, in the way it produces a blind-field:

La photo érotique [...] ne fait pas du sexe un objet central; elle peut très bien ne pas le montrer; elle entraîne le spectateur hors de son cadre, et c'est en cela que cette photo, je l'anime et elle m'anime. Le punctum est alors une sorte de hors champ subtil, comme si l'image lançait le désir au-delà de ce qu'elle donne à voir [...] (CC, p. 93)

The contrast between the flatness of clichés - what could be described as a listless studium caused by saturated images (what is recalled in Barthes's "bla-bla") - and the blindness caused by a lightning-like punctum is constantly reaffirmed in Calle's work. In fact, while throughout Des histoires vraies the artist objectifies herself (just as she objectifies men), embodying clichés of feminin158 ity-the strip-teaser, the blushing young girl, the nude model, the bride, the woman concerned with the size of her breasts, the obedient daughter-, each one of these stereotypes is estranged through the use of narratives infused with questions of fate, superstition and conspiracy: Calle the strip-teaser is hurt by a colleague who hits her in the forehead with a high-heel. Calle the nude model stops posing after one of the "artists," for the twelfth day in a row, lacerates his picture of her with a razor blade (she decides not to show up for the session on the thirteenth day). In fact, nowhere do we find a "simple," direct, what could be deemed "faithful" portrait of Calle; rather, not only are the narratives strange but in the photographs of Calle that accompany them, a part of her face or her body is either missing or in disguise: Calle is reduced to a picture of her breasts, a face wearing a plastic pig's nose, a profile, the back of a head, a nude drawing, a hat and wig, a wedding dress... and never does "the real Sophie Calle" appear. Calle-the-woman is nowhere to be seen, neither the real Sophie Calle nor what we could call a "real woman."

In a parallel way, while men are everywhere mentioned in her book, given a central place in the narratives, they are nowhere to be seen: Calle rarely photographs them (and when she does, their "male" bodies are transformed). Indeed, while her stories are strewn with constant failures in matters of love (a number of Calle's histoires vraies have to do with male abandonment, the first one being her father's), she herself renders them absent, makes them disappear; the presence of men is impaired, sabotaged. However, while men are never totally present, in Calle's work, nor are they completely absent. They are a trace, existing only through the stories that she tells of their disappearance, stories that make them vanish repeatedly.

In the performances that compose the three books included in Labsence (Souvenirs de Berlin-Est, Fantômes and Disparitions) Calle makes disappeared 
objects reappear (political monuments in East-Berlin, hidden during reunification; paintings that have been stolen from or lent by a museum, etc). Her goal is to bring them back to life through the descriptions that those who saw the objects can give of them. But most importantly, Disparitions begins with the story of three male disappearances, the deaths of three men that she loved: torero Manolo Montoliu killed in the Seville arena, Hervé Guibert from AIDS-related causes while Sophie Calle was in a plane flying to America (an episode included in the beginning of No Sex Last Night), and Jean-Marie, a friend who took his own life following a break-up. In each case, Calle was absent; she "did not see anything." Calle dedicates the works of Disparitions to the memory of these three friends. But just as she does for various objects, asking those who remember to describe them and revealing, through these narratives, memory's inaccuracy, Calle describes absent men: her descriptions can only be inadequate, partial failures that reveal memory as a form of lack, and reality as what remains of an act of perception that is necessarily incomplete.

Amnesia is central to Calle's relationship with men. She writes:

J'ai beau regarder, je ne me souviens ni de la couleur des yeux des hommes, ni de la taille, ni de la forme de leur sexe. Mais j'ai pensé qu'une épouse se doit de ne pas oublier ces choses-là. J'ai donc fait un effort pour combattre cette fâcheuse amnésie. Maintenant, je sais qu'il a les yeux verts. (HVD, p. 63)

This incapacity to recall the image of a man's penis is echoed in a number of her histoires vraies. Indeed, in "Revve de jeune fille," Calle describes having ordered a dessert called "A young girl's dream" in a restaurant, when she was a teenager. The waiter, smiling, drops a plate in front of her in which a peeled banana and two scoops of vanilla ice cream (represented in the accompanying photo) have been appropriately positioned. "J'ai retenu mes larmes et fermé les yeux," writes Calle, "ainsi que je le fis des années plus tard, lorsque, pour la première fois, un homme se mit nu devant moi." (HVD, p. 12-13) In the following caption, Calle describes this "first time" and how her lover agreed to never show himself naked in front of Calle "du côté du sexe" (HVD, p. 15). When he got up from bed in the morning light, he immediately put on a white bathrobe, photographed in the book, in order to hide himself, a garment that he gave to Calle when he ended his relationship with her.

In No Sex Last Night/Double Blind, Calle confides to Shephard her inability to remember a man's sexual organ. Included in "Le Mari," the tale "Lamnésie" (HVD, p. 62-63) is accompanied by a picture of a naked man who seems to be lying on a bed one arm hidden, the other lifted above his head, legs crossed and 
genitals tucked under. This man's genital organs resemble that of a woman-a pelvic triangle covered with pubic hair. And although the extended body and the arm's position recall an odalisque, the chest is clearly a man's. Neither man nor woman, then, this person-Calle's husband-, has no sex organs. ${ }^{14}$ No sex took place/there is no sex to remember.

In 1992, Calle and her partner, Greg Shephard, embarked on a road-trip across America. Their plan was to travel from New York to California where an artist residency awaited Calle.

Nous vivions ensemble depuis un an, mais notre relation s'était dégradée. Nous avions totalement cessé de nous parler. Je rêvais de l'épouser. Il rêvait de faire du cinéma. Pour l'inciter à traverser l'Amérique avec moi, j'avais proposé que nous réalisions un film durant le voyage. Il avait accepté.

De notre absence de communication, vint l'idée de nous munir chacun d'une caméra vidéo, et d'en faire la seule confidente de nos frustrations en lui racontant secrètement tout ce que nous ne pouvions pas nous dire.

La règle du jeu établie, le z janvier 1992, nous avons quitté New York dans sa Cadillac grise en direction de la Californie.

The couple's relationship was at a standstill and they decided to travel "to see if they could still love each other..." However, what Calle had in mind, paradoxically given the couple's precarious situation, was a wedding: she had asked Greg if he would marry her and throughout the film, she waits for his answer. The film's days and nights are filled with a growing estrangement made of conflicts, misunderstandings and silences, and every morning Calle, aiming her camera towards the empty conjugal bed, laments the absence of sexual contact: "No sex last night," she says, "No sex...," "No..." The film winds its way desperately through the US landscape, roadside delis and cheap motels, following the depressive trip of a couple on the edge of separation. As they both confess their disappointment to a camera, the film grows more and more melancholic, Calle watching her partner give a greater amount of "love" to his car than he does to her, Shephard suffering from Calle's persistent attempt to control him. To the audience, the relationship can only appear as a failure, the result of serious

14. This recalls the photo of Jane Gallop on the cover of Living with his Camera. We cannot tell that this picture is of a woman or a man holding a broom. "The fantasy housewife here has no face; her head, located at crotch level, is a mass of dark hair; her head has become pubic." (LWC, p. 3) 
miscommunication: not only do the lovers speak different languages (English and French), but Shephard does not understand Calle's sense of humor, taking what she says at face-value, and Calle is mystified by her lover's American culture. Nonetheless, and this is the piece's coup de théatre, as the film moves towards the end, Greg grows out of arguments against the awaited event and finally agrees to marry Sophie. A wedding ceremony takes place in his beloved car, in Las Vegas's Little White Chapel drive-up window. "Soyons réalistes," Calle says, "je dois mon mariage à une Cadillac."

This journey is recorded in Calle and Shephard's bilingual film Double Blind (entitled No Sex Last Night in its $35 \mathrm{~mm}$ version). The film's dual title represents the double aspect of the video-diary: throughout the trip, each partner filmed him or herself as well as each other. The camera functioned as a confessional and a witness through which a relationship was at once rekindled (they finally married) and buried, rendered visible and made to disappear. The title also clearly calls to mind the stereotypical male/female duality that the film represents. For if the film is, without question, a work of originality, it is clearly not so in matters of gender representation. Calle and Shephard embody the prototypical female and male: female desire for marriage, male fear of commitment, female nagging, male lying, female jealousy, male automotive love... However, it is impossible to know if what is shown is the real thing, if this is a "true" videodiary or simply make-believe. ${ }^{15}$

The ten stories added (+) to Calle's “true stories" can be viewed as the film's distillate. They are grouped under a common title: "Le mari." The place occupied by the trope of marriage in Calle's film and narrative series "Le mari" reveals her preoccupation with men specifically, and with sex generally-with the objects and institutions of sex. Throughout her work (and especially in the allegedly autobiographical Des histoires vraies + dix), Calle stages present relationships with men or refers to past ones, all of them failures, false or strange relationships that, it seems, inevitably lead to separations. ${ }^{16}$ Men occupy the place of absence

15. Complicating matters, Calle has thanked Greg Shepard for allowing them to make something out of a relationship that was dying.

16. In fact, Des histoires vraies is dedicated to a stranger met, through a common friend, after the man Calle had been living with for seven years left her. In her recent work, Douleur exquise, Calle tells the story of how, while on a trip to Japan, her then lover, on the eve of the day when he was supposed to meet up with her, broke off their relationship. Calle's pain was such that upon her return, she did two things: she told her story as often as necessary for the pain to wither away and asked a number of people to tell her the story of their worst experience of pain, stories that could then accompany hers. The 
in the tales Calle tells of her life, and this is the place that they are granted in her art. Indeed, the wedding dress present in the true/false wedding picture is also the subject of the following tale concerning a respected artist, admired by Calle since childhood and with whom she allegedly had a sexual relationship (the lost lover of Douleur exquise). After he "allowed" her to visit him, she left for his home carrying, in her suitcase, a wedding dress: she wore it for their first night together. The photograph that accompanies this tale is one of a slightly ruffled wedding dress, lying on what could be a bed sheet. The dress lies on the bed as if the person wearing it had suddenly vanished. The way the arms are set, the verticality of the dress's position recall the body that once was in it, that of an absent bride, a dead wife, an invisible, ghosted woman. Calle intimates that the marriage was consummated, but the first night seems to have been the last. ${ }^{17}$ This is also what the film No Sex Last Night/Double Blind suggests towards the end (as does the "true stories"'s caption entitled "Lérection"): retelling their trip and the fifteen sexless nights spent with her lover, Calle describes how, on the night of her wedding in Las Vegas, sex actually took place: "Il me confia que son désir était né du fait que j'étais devenue sa femme. Une érection: c'est la première chose que le mariage m'apportait." (HVD, p. 65)

The irony behind Calle's words is accentuated by the fact that throughout Des histoires vraies, the male sexual organ is constantly invoked as the thing that she cannot or will not look at. The impotent man, or limp penis, is but one part of this thread. Indeed, it is contained in the meaning of the film's title: No sex refers not only to the absent sexual act but to the ghosted sexual organ. The film's second title, Double Blind, obviously hints not only at this blindness (the inability to see the sexual organ) but at a double entendre: «double blind » is the name given to the conditions in which a scientific experiment is conducted, when one does not know, for instance, if real medication has been given or a placebo. In

two-part exhibit Douleur exquise (printed in the eponymous book) presents, on one hand, the tale of Calle's story told and retold 36 times, side by side with a picture illustrating it. As one walks through the exhibit or leafs through the pages, the narrative, which is both difference and repetition - the essence of the tale being always the same with variations in the language used-, progressively disappears: not only does the length of the text diminish but the ink fades away. In the end, we are left with a blank page.

17. This wedding dress is also visible in her installation Appointment with Sigmund Freud (in English in the text). Invited to exhibit her work in Freud's house in London, Calle chooses to introduce, in Freud's decor, sentimental objects used in her autobiographical stories. A picture of the exhibit shows the wedding dress lying on Freud's couch in the position of a patient. Like the vanished bride, the patient (Sophie Calle) is also absent. 
a similar way, what has Calle been given by Shephard in guise of a marriage (and what has she given him) in this film where two cameras, and those who use them, do not see each other, where a double blindness is being filmed? Where does truth lie?

Throughout the film made with her "husband," Calle bemoans the absence of sexual relations with him. "No sex last night," she says, shooting empty beds in sordid motels across America. Empty beds are strewn throughout Calle's work, from her first performances entitled Les dormeurs (1979) and L'hôtel (1981) to two of her most recent: Voyage en Californie (2003) and Douleur exquise (1984-2003). ${ }^{18}$ However, beds are not only often empty in Calle's work, carrying the trace of those who slept in them (ruffled sheets, hallowed mattress, scattered personal objects); they are also lent and borrowed, temporarily inhabited. In every case, a sexual relationship is evoked by the mere presence of a bed, but in every case, beds, it seems, can only be haunted by sex: desire is rarely carried out, sex seldom ever takes place. Indeed, Calle's work is ultimately the space of "no sex."

The last two captions of "Le mari" point to this particular form of ghosting. In "Le divorce," Calle writes: "Dans mes fantasmes, c'est moi l'homme." (HVD, p. 2-73) Revealing how her husband quickly understood the fact that, in bed, she wants to be the man, she goes on to describe a ritual, suggested by him in order to fulfill her desire, during which she would make him urinate: standing close behind him, she would unbutton his pants, take his penis in her hand, place it in the right position, aim correctly and then put it back inside and close the pant fly. After the couple's separation, Calle suggested that they make a photo of this ritual (which is reproduced in the book), a final monument to an ending relationship. "Ce cliché," she writes, "me servit de prétexte pour poser la main sur son sexe, une dernière fois. Ce soir-là j'acceptai le divorce." (HVD, p. 73) The picture shown is of a man urinating, his head cut off by the picture's frame, his penis held by a woman's right hand while her left one sits on the other side. The smallness of these hands and the presence of a ring serve to sexualize them. But however clear the ownership of the hands and penis appears to be, the picture shows a strange configuration: indeed, hands and body cannot be divorced. Who, then, is the owner of this sexual identity? There are four hands for a sexual organ which, in this case, is doubly possessed. It is not a question, then, as in Freudian tales, of who is castrated, but rather of who is supplemented. Indeed, while Calle's

18. In Voyage en Californie, after a young American man asks Calle if he can heal from a romantic break-up in her bed, she has her bed and beddings sent across the ocean to him, asking him to send them back to her once he is done using them. 
Histoires vraies tell the story of the male sexual organ's invisibility, and while here it is represented, she has taken it in her own hands; it is not a question, then, of castration, but of endless supplementation, of what more one can always have, of what can be added-as in the title Des histoires vraies + dix. It is not a question, for Calle, of owning the penis (something that the divorce picture could intimate), as if her work were an answer to Freud's endlessly repeated question "what does a woman want?" but of resisting the "YES sex:" not only the authenticity of a sexual relationship but the belief in indubitable sexual identities, a certainty inseparable from an unflinching gaze on reality and on identity in general.

In "Oedipus interruptus," Teresa de Lauretis asks "what manner of seduction operates in cinema to solicit the complicity of women spectators in a desire whose terms are those of the Oedipus ${ }^{19}$ "? Sophie Calle's work rejects such terms, the oedipal story line and the archetypal fashion in which a woman's desire is understood. In no way is she the prototype of a "daughter" hoping to replace the lost paternal object of love or striving to acquire the phallus, nor is she a blinded, ashamed Oedipus: a subject revealing herself "as she is" in autobiographical pieces in search of healing or absolution. Calle has nothing to hide and nothing to confess, and if she shuts her eyes in front of the male sexual organ, it is in order to refuse any affirmation that could jeopardize the flow of desire. In Calle's work, there is no true sexual relationship as there is no "true sex," as there is no one identity and no truth that could correspond to reality. One is tempted to find in Calle's play with presence and absence and the way in which she destabilizes reality and fiction, a response to Gilles Deleuze and Claire Parnet's injunction in Dialogues:

Nous avons retenu d'Edipe le sale petit secret, et non pas (Edipe à Colone, sur sa ligne de fuite, devenu imperceptible, identique au grand secret vivant. Le grand secret, c'est quand on n'a plus rien à cacher, et que personne alors ne peut vous saisir. [...] Ton secret, on le voit toujours sur ton visage et dans ton cil. Perds le visage. [...] "Moi, voilà comme je suis," c'est fini tout ça. ${ }^{20}$

19. Teresa de Lauretis, “Oedipus Interruptus," in Sue Thornham (ed.), Feminist Film Theory. A Reader, New York, New York University Press, 1999, p. 85.

20. Gilles Deleuze, Claire Parnet, Dialogues, p. 58-59. 